\title{
Effects of Various Semiconducting Oxides as Photoanode and Counter Electrode for Dye Sensitized Solar Cell Application - A Review
}

\author{
Fatiatun $^{1 *}$, Suriani Abu Bakar², Putut Marwoto ${ }^{3}$, Kusnanto Mukti Wibowo ${ }^{4}$, \\ Muqoyyanah² and Firdaus ${ }^{1}$
}
${ }^{1}$ Department of Physics Education, Faculty of Education and Teaching, Universitas Sains Al-Qur'an, Mojotengah, Wonosobo, 56351, Central Java, Indonesia
${ }^{2}$ Nanotechnology Research Centre, Department of Phyisics, Faculty of Science and Mathematics, Universiti Pendidikan Sultan Idris, 35900 Tanjung Malim, Perak, Malaysia
${ }^{3}$ Materials Research Group, Thin Film Laboratory, Faculty of Mathematics and Natural Science, Universitas Negeri Semarang, Sekaran, Gunungpati, 50229 Semarang, Indonesia
${ }^{4}$ Department of Electromedical Engineering, Faculty of Health Sciences, Universitas Muhamadiyah Purwokerto, 53182 Purwokerto, Indonesia
*Email: fatia@unsiq.ac.id

\begin{abstract}
Dye sensitized solar cells (DSSCs) were attractive as a promising photovoltaic technologies alternative. The DSSCs showed a low cost production, high power conversion efficiency and simple fabrication. In DSSCs, the photoanode have significant roles to collects the photo-excitation electrons and dye conducts photo-electrons to the transparent conducting film (TCF). Photoanode have a wide band gap semiconducting metal oxide (e. g. zinc oxide $(\mathrm{ZnO})$ and titanium dioxide $\left(\mathrm{TiO}_{2}\right)$ ) that were coated onto TCF. Counter electrode (CE) was one of important components in regulating the DSSCs application. The $\mathrm{CE}$ was used as mediator to generate the sensitizer after electron injection. The ideal of CE materials must have a low sheet resistance, low cost production, high electrical conductivity, good electro-catalytic activity and excellent stability. The CE materials commonly used for DSSCs application such as platinum (Pt), carbon, carbon nanotubes (CNTs), graphene and conducting polymers. The review has been developed to study the good characteristics of photoanode and CE materials for DSSCs application. Then, it was also used to give information towards the development of photoanode and CE materials for the next research in DSSCs application. In this review, the influence of various semiconducting oxides as photoanode and CE for DSSCs application were discussed.
\end{abstract}

Keywords : photoanode, counter electrode, dye sensitized solar cells

ABSTRAK

Dye sensitized solar cells (DSSCs) merupakan teknologi alternatif fotovoltaik yang menguntungkan. DSSCs menunjukkan harga yang murah, efisiensi yang tinggi dan proses pembuatan yang sederhana. Dalam aplikasi DSSCs, fotoanoda memiliki peranan yang penting untuk mengumpulkan elektronelektron yang tereksitasi dan dye berfungsi untuk menyalurkan cahaya elektron-elektron ke transparent conducting film (TCF). Fotoanoda mempunyai band gap yang lebar pada semikonduktor logam oksida (contoh: zinc oxide $(\mathrm{ZnO})$ dan titanium dioxide $\left(\mathrm{TiO}_{2}\right)$ ) yang dilapiskan pada TCF. Counter electrode (CE) adalah salah satu komponen yang penting dalam proses kerja DSSCs. CE digunakan sebagai mediator untuk membangkitkan sensitizer setelah masuknya elektron. Bahan CE yang ideal harus mempunyai resistansi yang rendah, biaya produksi yang murah, konduktivitas listrik yang tinggi, aktivitas elektrokatalitik yang bagus dan stabilitas yang tinggi. Bahan-bahan CE yang umum digunakan 
untuk aplikasi DSSCs yaitu seperti platina (Pt), karbon, carbon nanotubes (CNTs), grafin dan polimer konduktif. Review ini dikembangkan untuk mempelajari sifat-sifat bahan fotoanoda dan CE yang bagus untuk aplikasi DSSCs. Review ini juga digunakan untuk memberikan informasi untuk perkembangan bahan-bahan fotoanoda dan CE pada penelitian selanjutnya dalam aplikasi DSSCs. Dalam review ini, pengaruh bahan-bahan yang digunakan untuk fotoanoda dan CE dalam aplikasi DSSCs didiskusikan.

Kata kunci: fotoanoda, counter electrode, dye sensitized solar cells

\section{INTRODUCTION}

Energy was classified as basic human right in the form of an electricity. Energy is very important to human lives since it could reduce poverty, increase productivity, improves health and standards of living. The energy sources were consisted of three categories, (1) first from the chemical or photo-physical that oxidize some substance, such as solar radiation to generate electricity, (2) second derives from nuclear reactions, (3) and the third derives from thermo-mechanicals (e.g. wind, water, or geological sources) [1].

Among the other sources of energy, fossil fuels (e.g. oil, gas and coal) were used as the main source of energy which will decrease in the next century and shows the finite natural resources. Recently, non-conventional and renewable sources have been explored by many countries [2]. The nuclear, solar, bio and wind were used as source of energy alternative due to low cost production. Commonly, the sunlight was known as a primary source of energy and was usually used to generate electricity.

The development of solar cells has three generations since 1954. The first generation of solar cell was developed by Chapin that used crystalline silicon [3]. The silicon has the high cost production and weak absorption of sunlight. Then, the second generation used cadmium telluride (CdTe), copper indium (gallium) selenide (CIS/CIGS), amorphous and hybrid silicon thin films. However, in this generation has the lower power conversion efficiency than first generation. Finally, the third generation technology was developed by O'regan and Gratzel since 1991. This generation focused on the semiconducting materials due to have wide band gap [4-5], low cost and good performance in DSSCs application [6].

The DSSCs showed the most prominent in the third generation solar cells and better performance than conventional solar cells. The DSSCs were known as a photovoltaic and have low cost production to convert sunlight to electricity. It was also known as a photoelectrochemical cell and have photoelectrode based on a nanostructures metal-oxide film (e. g. $\mathrm{ZnO}, \mathrm{TiO}_{2}, \mathrm{SnO}_{2}, \mathrm{SrTiO}_{3}$ and $\mathrm{Nb}_{2} \mathrm{O}_{5}$ ) [7-9]. The DSSCs were introduced by O'Regan and Gratzel that were known as inorganic p-n junction solar cells and a promising alternative photovoltaic [8]. Recently, the DSSCs were developed and produced due to have low cost production, high power conversion efficiency, usage of medium purity materials, environmental friendliness, good performance in diverse light conditions, impressive incident photons to electrical current conversion efficiency and long-term stability [11-12].

Commonly, the DSSCs consists of five main components: (1) glass substrate of transparent conductive (TCF) (e. g. FTO and ITO); (2) semiconductor metal oxide layer (e. g. ZnO, $\mathrm{TiO}_{2}, \mathrm{SnO}_{2}, \mathrm{SrTiO}_{3}$ and $\mathrm{Nb}_{2} \mathrm{O}_{5}$ ) coated on TCF as photoanode [13]; (3) monolayer of organic/inorganic dye molecule on the surface of metal oxide layer in photoanode; (4) liquid phase electrolytes (e. g. iodide/tri-iodide $\left(\mathrm{I}^{-} / \mathrm{I}_{3}{ }^{-}\right)$) are used to regenerate the oxidized dye and (5) Pt or other materials (e. g. carbon, graphene and CNTs) as CE [14-15]. 


\section{Objectives of The Present Review}

In this review, the influence of photoanode and CE to power conversion efficiency in DSSCs application were discussed. Based on the literatures [15-16], research activities executed toward the modifications of photoanode and $\mathrm{CE}$ to increase the power conversion efficiency in DSSCs application. The other articles reported that every constituent (TCF, photoanode, dyes, electrolytes and CE) influenced to the performance of DSSCs. Meanwhile, the role of structural, optical, electrical properties and composition of materials in the photoanode and CE will also affect to the performance of DSSCs [17].

In the present review, we gave an illustration to illustrate the key role of photoanode and CE that will influence to the power conversion efficiency in DSSCs application. This description based on the relevant literatures and investigated about the DSSCs application.

\section{Dye Sensitized Solar Cells}

The DSSCs were a photovoltaic device that converts solar radiation into electricity. The schematic diagram of DSSCs and its components were shown in Figure 1. The system DSSCs consists of:

\section{Transparent conductive film}

The TCF was fabricated by conductive oxide layer on the glass substrate [18]. The conductive glass was used as substrate in photoanode and CE used to enhance the electrical conductivity and light transmittance. Commonly, the fluorine-doped tin oxide (FTO) and indium-doped tin oxide (ITO) were used as substrate in DSSCs application. Meanwhile, the resistivity of FTO substrate $\left(2.5 \%\right.$ of F) was $6 \times 10^{-4} \Omega \mathrm{cm}$ and ITO (6\% of $\mathrm{Sn}$ ) $8 \times 10^{-4} \Omega \mathrm{c}$ [19-20]. Therefore, the FTO substrate used in DSSCs due to has the higher power conversion efficiency of $\sim 9.4 \%$ than ITO $\sim 2.4 \%$ [21]. Therefore, the FTO substrate was highly recommended as TCF in this application. Figure 1 showed the structure and components of DSSCs. 


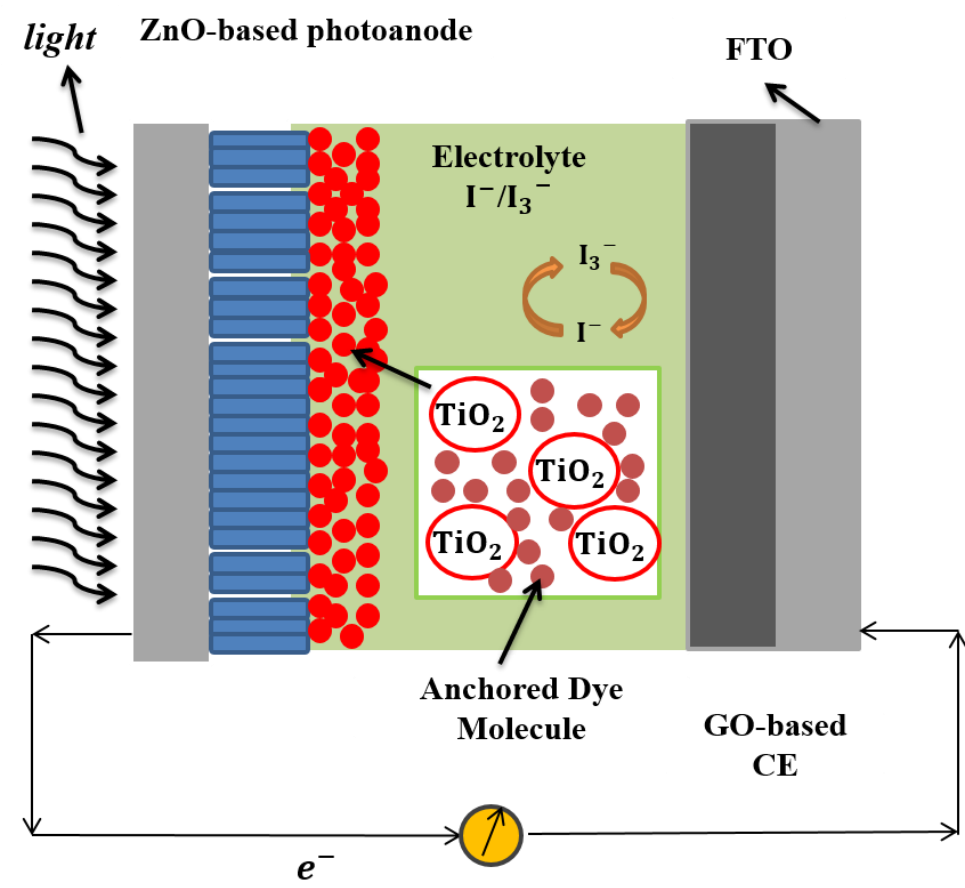

Figure 1. Structure and components of DSSCs.

\section{Photoanode}

Commonly, the photoanode has a wide band gap and fabricated by semiconducting metal oxides that was coated on TCF. The metal oxides were used to absorb dye molecules, collect the photo-generate electrons from the excited state and conduct photo-electrons from dye to the conducting substrate [11]. Therefore, metal oxides have to have a good electrical and stability properties to against photo-corrosion. Actually, photo-corrosion was caused by oxidation of holes with the redox electrolytes that will influence to the performance in DSSCs application [22]. Meanwhile, the photoanode were used to collect and transport photo-excitation electron from dye to $\mathrm{CE}$. Based on previous research, the ideal photoanode supposedly have high surface area for dye adsorption, high porous for effective mass transport and high electron mobility for efficient electron transport [23]. The metal oxides such as $\mathrm{ZnO}$ [15], $\mathrm{TiO}_{2}$ [23], $\mathrm{SnO}_{2}$ [24], $\mathrm{SrTiO}_{3}$ [25], $\mathrm{Zn}_{2} \mathrm{SnO}_{4}$ [26] and $\mathrm{Nb}_{2} \mathrm{O}_{5}$ [27] have been widely used as photoanode materials for DSSCs application.

The power conversion efficiency of metal oxides as photoanode is showed in Table 1. Theoretically, wide band gap was needed in photoanode due to an electron with energy (hv) will be excited to the conduction band when has high exceeds the band gap of a semiconductor. Consequently, electron was excited leave hole (positive charge) at the valence band. These charges can be changed to electrical current by chemical reaction [28]. Among the semiconducting metal oxides, the $\mathrm{TiO}_{2}$ was mostly used as photoanode material. Actually, the $\mathrm{TiO}_{2}$ has three crystalline forms such as rutile, anatase and brookite phase. The rutile phase has band gap of $3.05 \mathrm{eV}$ with tetragonal structure. Then, the anatase phase has band gap of $3.23 \mathrm{eV}$ that has been also tetragonal structure and orthorhombic structure for brookite with band gap of $3.26 \mathrm{eV}$ [29]. However, the rutile and anatase phase of $\mathrm{TiO}_{2}$ nanoparticles have been studied for DSSCs application. 
The rutile phase was widely used in photoanode due to has better light scattering, more stable than anatase phase and higher refractive index of 2.71 than the anatase phase 2.53 [30]. Meanwhile, the rutile phase has higher wavelength in incident photon-to-current conversion efficiency (IPCE) of 400-750 nm than anatase phase 500-550 nm [31]. However, the rutile crystals were usually formed in high temperature process, whereas the anatase phase stable at low temperature [32]. Commonly, the brookite phase was not used as photoanode in the DSSCs application due to difficult in production [33].

Table 1. Comparison performance of photoanode materials (metal oxides) in DSSCs application

\begin{tabular}{ccccc}
\hline $\begin{array}{c}\text { Photoanode } \\
\text { Material }\end{array}$ & $\begin{array}{c}\text { Band gap } \\
(\mathbf{e V})\end{array}$ & Method & $\boldsymbol{\eta ( \% )}$ & References \\
\hline $\mathrm{TiO}_{2}$ & 3.2 & Hydrothermal & 7.13 & {$[34]$} \\
$\mathrm{ZnO}$ & 3.3 & Blending & 4.59 & {$[35]$} \\
$\mathrm{Nb}_{2} \mathrm{O}_{5}$ & 3.4 & Doctor Blade & 0.64 & {$[27]$} \\
$\mathrm{Zn}_{2} \mathrm{SnO}_{4}$ & 3.6 & Hydrothermal & 3.36 & {$[26]$} \\
$\mathrm{SrTiO}_{3}$ & 3.2 & Hydrothermal & 5.07 & {$[36]$} \\
$\mathrm{WO}_{3}$ & $2.6-3.0$ & Sol-gel & 4.63 & {$[37]$} \\
$\mathrm{SnO}_{2}$ & 3.8 & Electrospinning & 3.41 & {$[38]$} \\
\hline
\end{tabular}

Besides of $\mathrm{TiO}_{2}$, the $\mathrm{ZnO}$ was a promising alternative metal oxide due to wide band gap, relatively high electron mobility $\left(\sim 100 \mathrm{~cm}^{2} \mathrm{v}^{-1} \mathrm{~s}^{-1}\right)$ than $\mathrm{TiO}_{2}$ and large excitation binding energy $(60 \mathrm{meV})[15]$. However, the $\mathrm{TiO}_{2}$ has the highest power conversion efficiency than $\mathrm{ZnO}$ in DSSCs performance. $\mathrm{The}^{\mathrm{TiO}_{2}}$ and $\mathrm{ZnO}$ nanostructures can be produced with a large surface area that showed a primary factor in maximizing dye absorption of photoanode for DSSCs application [7, 39].

The $\mathrm{ZnO}$ has three crystalline forms: hexagonal wurtzite, cubic zinc blende and cubic rock salt. Among these crystalline forms, the hexagonal wurtzite was the most stable at ambient condition that showed the majority form of crystal [40]. Meanwhile, the $\mathrm{ZnO}$ nanostructures have category of 1-D, 2-D and 3-D. However, the 1-D nanostructures were usually used in DSSCs application due to the electrons can easily migrate, compared with nanoparticles. Meanwhile, the 1 -D nanostructures have a high light scattering to enhance the cells performance and high surface area to absorb dye molecules [14]. The nanostructures were used as photoanode due to have trigger fast electron transport and capable to absorb dye effectively [39].

The microstructures, particle size, porosity and pore size distribution in the metal oxides showed a key role in photoanode that was used to enhance the photovoltaic performance. Moreover, the doping on the metal oxides materials will affect to the structural, optical and electrical properties of photoanode. The technique preparation will also influence to the results of performance in DSSCs application [15]. 


\subsection{Effect of doping in photoanode materials}

In semiconducting metal oxides, doping cation/anion will change band gap and improve the electrical properties. Meanwhile, the ion doping was used to reduce recombination resistance in photoanode [41]. Injection and transportation of photo-excitation electrons will influence to the power conversion efficiency of DSSCs [14]. Hence, the cations were used as dopant in metal oxides due to large dipole moment that will affect to the electron transfer [42]. The $\mathrm{ZnO}$ and $\mathrm{TiO}_{2}$ were usually used as photoanode in DSSCs application which can absorbs UV light due to have wide band gap of $3.2-3.3 \mathrm{eV}$. In $\mathrm{TiO}_{2}$, cations and anions were used as dopant that can improve the power conversion efficiency in this application. Based on literature, the different of cationic dopants and power conversion efficiency in $\mathrm{TiO}_{2}$ material were shown in Table 2. Then, Table 3 showed the performance of DSSCs with the different anionic dopants in $\mathrm{TiO}_{2}$ as photoanode in DSSCs application.

Table 2. Comparison performance of DSSCs with different cationic dopants in $\mathrm{TiO}_{2}$ material as photoanode

\begin{tabular}{ccc}
\hline Cationic Dopant & $\boldsymbol{\eta}(\%)$ & References \\
\hline Scandium $(\mathrm{Sc})$ & 9.6 & {$[43]$} \\
Magnesium $(\mathrm{Mg})$ & 8.04 & {$[44]$} \\
Niobium $(\mathrm{Nb})$ & 7.3 & {$[45]$} \\
Chrome $(\mathrm{Cr})$ & 3.89 & {$[46]$} \\
Cuprum $(\mathrm{Cu})$ & 0.44 & {$[47]$} \\
(Tantalum $(\mathrm{Ta}))$ & 8.18 & {$[48]$} \\
(Vanadium $(\mathrm{V}))$ & 7.8 & \\
\hline
\end{tabular}

Among the cationic dopants in $\mathrm{TiO}_{2}$, the Sc showed the highest power conversion efficiency than the others due to size $\mathrm{Sc}^{3+}$ rather similar with the $\mathrm{Ti}^{4+}$. Therefore, the Sc cationic dopant can decrease defects in $\mathrm{TiO}_{2}$ as photoanode [43]. Meanwhile, Ta and $\mathrm{Mg}$ dopant can also improve the power conversion efficiency in DSSCs application.

Table 3. Comparison performance of DSSCs with different anionic dopants in $\mathrm{TiO}_{2}$ as photoanode

\begin{tabular}{ccc}
\hline Anionic Dopant & $\boldsymbol{\eta}(\%)$ & References \\
\hline Fluoride (F) & 8.31 & {$[49]$} \\
& 5.24 & {$[48]$} \\
Nitrogen (N) & 4.7 & {$[50]$} \\
Sulfur (S) & 6.91 & {$[51]$} \\
Boron (B) & 4.61 & {$[52]$} \\
Carbon (C) & 3.9 & {$[53]$} \\
\hline
\end{tabular}

Based on the Table 3, F dopant showed the highest power conversion efficiency than the others anionic dopants. The F dopant can enhance the power conversion efficiency, reduce the charge recombination and contact resistance in photoanode [49]. Therefore, the F dopant can improve the $\mathrm{TiO}_{2}$ properties and can be developed in this application. Meanwhile, $\mathrm{N}$ and $\mathrm{S}$ anionic dopant in $\mathrm{TiO}_{2}$ can also increase the power conversion efficiency in DSSCs. Besides in $\mathrm{TiO}_{2}$, the $\mathrm{ZnO}$ can be also doped with the cationic dopants that was used to 
enhance the absorption of visible light. Table 4 showed the performance of DSSCs with different cationic dopants into $\mathrm{ZnO}$ as photoanode in DSSCs performance.

Table 4. Comparison performance of DSSCs with different cationic dopants in $\mathrm{ZnO}$ as photoanode

\begin{tabular}{ccc}
\hline Cationic Dopant & $\boldsymbol{\eta}(\%)$ & References \\
\hline Gallium $(\mathrm{Ga})$ & 3.19 & {$[54]$} \\
Magnesium $(\mathrm{Mg})$ & 4.19 & {$[55]$} \\
Aluminum $(\mathrm{Al})$ & 1.02 & {$[56]$} \\
Potassium $(\mathrm{K})$ & 0.012 & {$[57]$} \\
\hline
\end{tabular}

Among the cationic dopants in $\mathrm{ZnO}$, the $\mathrm{Mg}$ has the highest power conversion efficiency than the others. The $\mathrm{Ga}, \mathrm{Mg}$ and $\mathrm{Al}$ dopants in $\mathrm{ZnO}$ will affect to the photovoltaic properties and improve the power conversion efficiency in DSSCs performance [55]. Overall, doping cations/anions were promising affect in photoanode performance in DSSCs application.

\subsection{Effect of $\mathrm{ZnO}$ and $\mathrm{TiO}_{2}$ layer in the photoanode properties}

In photoanode, semiconducting metal oxides layer influenced the structural, optical and electrical properties. The researchers used $\mathrm{TiO}_{2}$ as photoanode due to improve the power conversion efficiency in DSSCs application [23]. Besides $\mathrm{TiO}_{2}$, the $\mathrm{ZnO}$ was also used as photoanode in DSSCs application.

Among these metal oxides materials, $\mathrm{TiO}_{2}$ and $\mathrm{ZnO}$ have high power conversion efficiency in DSSCs performance. Hence, the $\mathrm{TiO}_{2}$ and $\mathrm{ZnO}$ were used as photoanode materials in DSSCs application. Moreover, Table 5 showed the various morphology of $\mathrm{TiO}_{2}$ and its performances as photoanode. The $\mathrm{TiO}_{2}$ has good chemical stability under visible irradiation, cheap, non-toxic, and ready available due to its stability and better of power conversion efficiency [32]. Meanwhile, the power conversion efficiency of $\mathrm{TiO}_{2}$ as photoanode was strongly depended on light harvesting [58].

Based on Table 5, the 1-D of $\mathrm{TiO}_{2}$ nanorods were usually used as photoanode. The $\mathrm{TiO}_{2}$ nanorods were used in this alippcation due to can decrease the interconnections between crystalline titania particles that were compared to a porous titania film [59]. The $\mathrm{TiO}_{2}$ nanorods have diameters around of $99 \mathrm{~nm}$ and length $310 \mathrm{~nm}$ [39]. The nanorods structures have rapid transport of charge carriers and power conversion efficiency $~ 9.21 \%$ [60]. Meanwhile, the $\mathrm{TiO}_{2}$ nanotubes structures can also attribute to the synergistic effect due to have large surface area, fast charge transport and superior light scattering [61]. 
Table 5. Various morphologies and performances of $\mathrm{TiO}_{2}$ as photoanode in DSSCs application

\begin{tabular}{cccc}
\hline Morphology & Method & $\boldsymbol{\eta ( \% )}$ & References \\
\hline Nanoflowers & Hydrothermal & 6.63 & {$[62]$} \\
Nanorods & Hydrothermal & 1.86 & {$[63]$} \\
Nanotubes & Electrochemical & 7.24 & {$[61]$} \\
& Anodization & & \\
Nanowires & Hydrothermal & 4.32 & {$[64]$} \\
Nanosheets & Hydrothermal & 7.51 & {$[65]$} \\
Nanoflakes & Hydrothermal & 4.5 & {$[66]$} \\
\hline
\end{tabular}

Among the methods in Table 5, the $\mathrm{TiO}_{2}$ nanostructures were usually grown by hydrothermal method. This method was used to grow $\mathrm{TiO}_{2}$ nanoflowers, nanorods, nanowires, nanosheets, nanoflakes and to get highly crystalline [39]. The hydrothermal method was a powerful to synthesis of inorganic nanocrystal and high crystallinity without post synthetic annealing. Meanwhile, this method results the highest power conversion efficiency than the other methods. The hydrothermal method has a low temperature and simple to produce photoanode in DSSCs application. This method has also fast diffusion process reactions compared to the other methods. Besides the hydrothermal method, electrochemical anodization method was also used to grow $\mathrm{TiO}_{2}$ nanotubes due to high power conversion efficiency in DSSCs application.

Besides $\mathrm{TiO}_{2}$, the $\mathrm{ZnO}$ was also used as photoanode due to wide band gap energy [5] and higher electron mobility than $\mathrm{TiO}_{2}$ [67]. The $\mathrm{ZnO}$ presented superior electron mobility that enabled faster transport of photo injection electrons [69]. However, the power conversion efficiency of $\mathrm{ZnO}$ still lower compared to the $\mathrm{TiO}_{2}$ [16]. Therefore, the researchers were suggested to improve the $\mathrm{ZnO}$ metal oxides properties that was used to increase the power conversion efficiency in DSSCs performance. The overall power conversion efficiency of $\mathrm{ZnO}$ can be improved by increasing the dye capacity and decreasing the recombination effect in the cell. The $\mathrm{ZnO}$ nanostructures were fabricated to improve power conversion efficiency and light harvesting of the cell. Various morphologies and performances of $\mathrm{ZnO}$ as photoanode in DSSCs application were shown in Table 6. The structures such as nanorods, nanotubes and nanowires were usually used in photovoltaic cells due to photoactive materials as well as electrodes.

Among the other methods to grow $\mathrm{ZnO}$ nanostructures as shown in the table 6 , the solvothermal has the highest power conversion efficiency than the others. This method was used to grow $\mathrm{ZnO}$ nanorods and nanoflakes structures. Moreover, the solvothermal method has low temperature, simplicity, high purity and good homogenecity [69]. Meanwhile, the sol-gel immersion method was also used to prepare of metal oxide structures and film coatings. Usually, this method also to grow aligned $\mathrm{ZnO}$ nanorods thin film on a glass substrate. Sol-gel immersion has high quality of aligned $\mathrm{ZnO}$ nanorods. This method was started with preparing the solution by a sonicated sol-gel and immersion method to grow $\mathrm{ZnO}$ nanorods [70]. Moreover, this method has low cost production, simplicity, capability to control the growth of $\mathrm{ZnO}$ nanorods and low temperature deposition process. 
Table 6. Various morphologies and performances of $\mathrm{ZnO}$ as photoanode in DSSCs application

\begin{tabular}{cccc}
\hline Morphology & Method & $\boldsymbol{\eta}(\mathbf{\%})$ & References \\
\hline Nanowires & Hydrothermal & 5.7 & {$[71]$} \\
Nanorods & Solvothermal & 5.2 & {$[72]$} \\
& Sol-gel Immersion & 0.59 & {$[73]$} \\
& Hydrothermal & 0.22 & {$[74]$} \\
Nanosheets & CBD (Chemical & 5.16 & {$[75]$} \\
& Bath Deposition) & & \\
Nanoflakes & Solvothermal & 3.64 & {$[76]$} \\
Nanoflowers & Hydrothermal & 3.0 & {$[77]$}
\end{tabular}

The hydrothermal method was also used to grow $\mathrm{ZnO}$ nanorods, nanowires and nanoflowers. The hydrothermal method has low temperature and simplicity. However, this method required a long time in order to get a good crystallinity and low efficiency than solvothermal method when used to grow $\mathrm{ZnO}$ nanorods. Then, the chemical etching method was used to grow $\mathrm{ZnO}$ nanotubes that has a low temperature, good electrical properties but low power conversion efficiency in DSSCs application. Meanwhile, the $\mathrm{ZnO}$ nanosheets were grown by CBD method. The CBD method has advantages such as simple to fabricate, low cost, low evaporation temperature and high power conversion efficiency in DSSCs.

Based on types of morphologies, the $\mathrm{ZnO}$ nanorods showed the higher power conversion efficiency than $\mathrm{ZnO}$ nanoparticles that grown by solvothermal method [79]. The $\mathrm{ZnO}$ nanorods used as photoanode due to good performance in DSSCs application that provide a better electron transport [59]. The $\mathrm{ZnO}$ nanorods usually grown on seeded catalyst that used to reduce the thermodynamic barrier [78]. The materials were usually used as seeded catalyst such as aluminium ( $\mathrm{Al})$ [79], magnesium $(\mathrm{Mg})$ [7], magnesium oxide $(\mathrm{MgO})$ [80], silicon dioxide $\left(\mathrm{SiO}_{2}\right)$ and aurum $(\mathrm{Au})[81]$.

Hence, the presence of seeded catalyst has benefit to reduce the lattice mismatched effect during the growth of $\mathrm{ZnO}$ nanostructures on $\mathrm{Si}$ or FTO substrate by sol-gel immersion method. Seeded catalyst was influenced by speed up the rate of chemical reaction during the synthesis process. Meanwhile, the seeded catalyst used as the growth of $\mathrm{ZnO}$ nanorods [82]. Among the seeded catalyst materials, $\mathrm{Mg}$ showed a good seeded catalyst for growth of $\mathrm{ZnO}$ nanorods. The $\mathrm{Mg}$ used as seeded catalyst due to has almost similar ionic radii of $\mathrm{Mg}^{2+}(0.72$ $\AA$ ) and $\mathrm{Zn}^{2+}(0.74 \AA)$ that was believed to give less lattice distortion when $\mathrm{Zn}^{2+}$ was replaced with $\mathrm{Mg}^{2+}$ [83].

The $\mathrm{ZnO}$ nanowires have type like 'nanoforest' that have high density, long branched 'treelike' hierarchical by hydrothermal method. The branch network of crystalline $\mathrm{ZnO}$ nanowires can increase the electron diffusion and enhance rate of electrons transportation [16]. The $\mathrm{ZnO}$ nanowires has power conversion efficiency of $\sim 5.7 \%$ that were grown by hydrothermal method [71]. The superior performance of DSSCs was affected by a better light scattering, adequate dye loading and good electron transport [14].

Beside of $\mathrm{TiO}_{2}$ and $\mathrm{ZnO}$, bilayer $\mathrm{Zn}$-doped $\mathrm{TiO}_{2}$ was also used as photoanode in DSSCs application. The $\mathrm{Zn}$ on $\mathrm{TiO}_{2}$ layer in photoanode used to change the existing crystalline phases as well as degree of crystallinity, morphology, distribution and particle size. Meanwhile, the $\mathrm{Zn}$ can enhance photo-catalytic activity of $\mathrm{TiO}_{2}$ [84]. The synthesis of 
bilayer $\mathrm{Zn}$-doped $\mathrm{TiO}_{2}$ with $\mathrm{Zn}$ over $\mathrm{TiO}_{2}$ layer was fabricated by hydrothermal method [85]. The bilayer $\mathrm{Zn}$-doped $\mathrm{TiO}_{2}$ has the lower density and good for efficient electron in photoanode. The $\mathrm{Zn}$ on $\mathrm{TiO}_{2}$ layer can improve the performance of DSSCs that showed the higher power conversion efficiency $(\sim 8 \%)$ than mono-layer $\mathrm{TiO}_{2}$ [86]. Bilayer structures consisted of an over and under layer that were used light scattering for boosting the optical absorption of photoanode [16]. Consequently, the more light can be absorbed and the electron-hole pair injections were occurred.

\section{Photo-sensitizer}

In DSSCs, dye was used as photo-sensitizer on the surface of photoanode. Dye molecules adsorbed light photons in visible region and near infrared region of solar spectra. Meanwhile, the dye created photo-excitation electrons due to the presence of sun light. Afterwards, the photo-excitation electrons were injected into the conduction band of the semiconducting metal oxides that dye can rapidly regenerate over electron donation from the liquid electrolyte [14]. The dye has properties such as photo-stable, stable chemically, thermally and does not forms aggregates [87]. Moreover, the dye must has efficient electron injection into the conduction band of the semiconductor and strong adsorption onto the semiconductor surface [32]. Actually, the dye has three categories: inorganic, organic and natural dyes.

The dye ruthenium based inorganic (e.g. N3, N719, Z907 and black dye) was used as photosensitizer that has a high power conversion efficiency around of 10-11\% [88]. However, this inorganic dye has a high cost. Meanwhile, the organic dyes were also used as photosensitizer in DSSCs application. The green porphyrin was used as organic dye sensitizer in the aryl group and as an electron donor that malonic acid groups acted as an acceptor [89]. Based on the other researchers, dyes have an electron donor-acceptor that were used to make ease in charge transfer and power conversion efficiency up to $12.5 \%$ [90]. Actually, the organic dyes were cheaper, more environmental friendliness than inorganic dyes and good performance as sensitizers in DSSCs application, but narrow absorption spectra [87].

Besides synthetic inorganic and organic dyes, natural dyes were also used as a photosensitizer in DSSCs application. The natural dyes (e.g. carotenoid, betalain, chlorophyll and anthocyanin) were extracted from flowers, fruits and leaves that were used as photosensitizer [91]. The natural dyes were easily extracted, readily available, no need further purification, low cost production and environmental friendly [2]. Usually, natural dyes have a high efficiency up to $\sim 0.56 \%$ with high stability [92]. Compare to the other dyes, inorganic dyes were selected as photo-sensitizer due to its high power conversion efficiency than organic and natural dyes in DSSCs application.

\section{Electrolyte}

The electrolyte in DSSCs acted as a medium to transfer electrons from the CE to the oxidized dye and also regenerated the oxidized dye. Based on their physical state, the electrolytes can be classified mainly into three categories namely liquid, quasi-solid and solid electrolyte. 


\subsection{Liquid electrolyte}

The types of liquid electrolyte were redox couple, organic solvent and additives. However, the iodide/tri-iodide $\left(\mathrm{I}^{-} / \mathrm{I}_{3}{ }^{-}\right)$redox couple system was mostly studied and developed in DSSCs application [17]. The redox couple was made by mixing parts of chemical species in different oxidation states that can oxidize the agent in an electrochemical reaction. The good properties of redox electrolytes must have ionic mobility, solubility of a redox couple, driving force for the dye regeneration, fast electron transfer kinetics [17], high conductivity, relative high stability, not cause desorption of the dye from the photoanode, low cost and easy preparation [87]. Meanwhile, the significant characteristics of electrolyte were stability and efficiency in DSSCs performance [92]. Commonly, the iodide/tri-iodide $\left(\mathrm{I}^{-} / \mathrm{I}_{3}{ }^{-}\right)$redox couple was used as electrolyte due to have a better performance in DSSCs application. The iodide/tri-iodide $\left(\mathrm{I}^{-} / \mathrm{I}_{3}{ }^{-}\right)$electrolyte has advantages in kinetic properties, such as fast oxidation of $\mathrm{I}^{-}$at the photoanode/electrolyte for efficient dye regeneration and slow reduction of $\mathrm{I}_{3}{ }^{-}$at the electrolyte/CE interface for high carrier collection [92].

The $\mathrm{I}^{-} / \mathrm{I}_{3}{ }^{-}$electrolyte has drawbacks such as the absorption of visible light at $430 \mathrm{~nm}$ and corrosion of the metal CE (e.g. Pt, and $\mathrm{Au}$ ) [93]. Then, the power conversion efficiency of $\mathrm{I}^{-} / \mathrm{I}_{3}{ }^{-}$electrolyte around $\sim 11 \%$ in DSSCs application [94]. The concentration of $\mathrm{I}^{-} / \mathrm{I}_{3}{ }^{-}$redox couple has a key role in DSSCs performance. The low iodine concentration will difficult to maintain sufficient electrolyte conductivity and rapid redox reaction. Meanwhile, the high iodine concentration, electron recombination at the semiconducting metal oxide interface will decrease the performance of DSSCs and redox couple will increase the rate of light absorption [95]. The major drawback of $\mathrm{I}^{-} / \mathrm{I}_{3}{ }^{-}$redox couple was the higher driving force for reduction of the dye [87].

Then, the organic solvent (e.g. acetonitrile, 3-methoxy propionitrile, ethylene carbonate) not used in DSSCs application due to have a low viscosity, high dielectric constant and optimum donor number (14-20) of solvents [96]. Moreover, the additives were used as electrolyte and to adsorb on titanium surface (semiconducting metal oxide). It served as a barrier to the recombination reaction between the injected electrons in the metal oxide semiconductor [97].

\subsection{Quasi-solid electrolyte}

Besides on liquid electrolytes, quasi-solid electrolytes and solid-state electrolytes were also used in DSSCs application. The quasi-solid electrolyte such as ionic liquid (e.g. bis (imidazolium), 1-propargyl-3-methylimidazolium) iodides and polymer gel (e. g. polyvinyl acetate and poly (ethylene oxide)) contained redox couple. The couple redox was used as quasi-solid electrolyte to overcome the problems and volatile of liquid electrolyte [98]. The power conversion efficiency of DSSCs used quasi-solid electrolyte around 8-9\% [98]. However, the quasi-solid electrolyte has thermodynamic instability under high temperature, still suffer from solvent leakage and also require sealing when were used in high environment temperature [97]. 


\subsection{Solid state electrolyte}

Solid state electrolyte has various hole transporting materials that was investigated as a hole acceptors to replace liquid electrolytes [97]. Moreover, solid state electrolyte has a better mechanical stability and simply fabrication process. The power conversion efficiency of solid-state electrolyte $\sim 5 \%$ in DSSCs application. However, the solid state electrolyte has a high recombination reaction, low conductivity and ineffective contact with the CE [99].

\section{Counter Electrode}

The CE was one of the important components in DSSCs application. The main tasks of CE were (a) to regulate the DSSCs by catalysing the reduction of the iodide-tri-iodide redox species and as a mediator to generate the dye sensitizer after electron injection, or (b) to collect the hole from the transport materials in a solid state of DSSCs [100]. The ideal CE materials must have a low sheet resistance, low cost, good chemical stability, high electrical conductivity to charge transport and good electro-catalytic activity to reduce the redox couple $[93,101]$.

The metal Pt was popular catalyst as CE material in DSSCs application. The Pt has a high electro-catalytic activity to the reduction of redox couples in liquid electrolytes, highly transparent, high power conversion efficiency [102] and high electrical conductivity. The $\mathrm{Pt}$ catalyst was used as CE due to can help in regeneration of $\mathrm{I}^{-}$from $\mathrm{I}_{3}{ }^{-}$and collect of electron from the external load to the electrolyte [100]. However, Pt was expensive metal, diminishing supply and corrosion in liquid electrolyte. Recently, much effort has been made to reduce or replace Pt-base electrodes as CE in DSSCs application [16]. Consequently, other materials such as carbon, CNTs, graphene and conducting polymers have been also used as CE materials [103-104]. Carbonaceous were used to replace Pt as CE in DSSCS due to inexpensive and readily available.

\subsection{Carbon}

Carbon was mainly produced by incomplete combustion in industry. It was a promising material for $\mathrm{CE}$ due to has a high electrical conductivity, low cost, high surface area and high electro-catalytic activity towards the $\mathrm{I}^{-} / \mathrm{I}_{3}{ }^{-}$redox species [105]. Meanwhile, carbon has also high crystallinity favourable. The thickness of carbon layer on the substrate was important due to affect the catalysis and resistance of material. Carbon has a power conversion efficiency up to $\sim 6.97 \%$ by thermal deposition method in DSSCs application [106].

\subsection{Carbon nanotubes}

The CNTs were actually a carbon and successfully attract the attention of researcher community in 1991. The CNTs have three structures due to their number of roll walls such as single-walled carbon nanotubes (SWCNTs), multi-walled carbon nanotubes (MWCNTs) and double-walled carbon nanotube (DWCNTs). The CNTs have chemical stability, high electrical conductivity, mechanical properties and thermal conductivity [15]. The structure of SWCNTs and MWCNTs were usually used as CE in DSSCs application. The MWCNTs 
have efficiency of $\sim 4.2 \%$ by using electrochemical deposition method, good electro-catalytic activity and higher surface area than Pt [107]

\subsection{Graphene}

Graphene has been extensively explored to replace noble metal (Pt) as CE. Graphene has become the main research $h$ object for the last few decades due to its outstanding properties. It has high thermal and electrical conductivity [108-109]. Meanwhile, graphene has high surface area around of $2630 \mathrm{~m}^{2} \mathrm{~g}^{-1}$ that the higher than CNTs and decrease the charge transfer resistance [110]. Graphene has also high chemical and mechanical robustness [111]. Meanwhile, graphene has a low-cost production, simple preparation, high optical transparency, good electro-catalytic activity, environmental friendliness. Graphene has been intensively used as CE and yielded high-performance in DSSCs application [137].

In addition to photovoltaic, graphene has been also recognized in other application such as electronics and energy storage devices [113]. Actually, graphene has similar characteristics with CNTs. Graphene can be applied to DSSCs, fuel cells, supercapasitor and chemical sensor devices. Meanwhile, graphene as a new material for CE and has a high power conversion efficiency of $\sim 8.03 \%$ was successfully fabricated by using spin coating method [112]. Whereas, the power conversion efficiency used Pt as CE of $\sim 5.09 \%$ in DSSCs application [104]. These results showed that the graphene higher power conversion efficiency than Pt for CE in DSSCs application.

Graphene has nanosheets and nanoplatelets structure as CE in DSSCs application. However, graphene nanosheets were usually used as $\mathrm{CE}$. The graphene nanosheets were prepared from graphite by oxidation-reduction. The graphene oxide (GO) can be synthesized by electrochemical exfoliation method [7]. Commonly, this method was assisted by surfactant. The commercial sodium dodecyl sulphate (SDS), sodium dodecylbenzene sulphonate (SDBS), poly (sodium 4-styrenesulfonate) (PSS) and custom-made surfactant used was sodium 1, 4-bis (neopentyloxy)-3-(neopentyloxycarbonyl)-1, 4-dioxobutane-2-silphonate (TC14) can be used as surfactant in this method. However, the commercial SDS and custommade TC14 surfactants were used to assist during the electrochemical exfoliation method [15]. This method consumes a less chemicals and suitable to produce graphene flakes due to simple preparation, low cost production and low temperature [7]. Hence, the electrochemical exfoliation method was the most efficient method to produce GO.

Meanwhile, hummers method was also used to produce GO [114]. Hummers method gained intensive attention due to has a high efficiency, safety reaction and short reaction time [115]. However, this method was included non-cost effective due to high consumption of strong acids, high defects level on the sample and difficult to control the thickness of graphene sheets. Besides electrochemical exfoliation and hummers method, GO can be also produced by chemical vapour deposition (CVD) [116]. This CVD method can produce a low defect graphene on substrate that used argon as the carrier gas in the chamber. However, this method used a high temperature to oxidize graphite that caused less efficient and high energy consumption. Nowadays, this method was rarely used to produce graphene.

In addition, hydrazine hydrate was used as reducing agent to produce reduced graphene oxide ( $\mathrm{rGO}$ ) from $\mathrm{GO}$ by using reduction process. The reduction process was used to reduce 
the oxygen content in GO solution. The rGO showed a better electro-catalytic activity than the GO [117]. The rGO was attractive and unique due to has a capability to produce singlelayer graphene and low cost production. Commonly, the transfer process of GO and rGO to fabricate thin film was prepared by using spray deposition method.

Spray deposition method was used due to low cost, fast and simple to fabricate highly conductive films for electronic device applications [7]. Prior spray process, solution was sonicated (commercial SDS and custom-made TC14 surfactants) for 5 mins. Then, GO and rGO were sprayed onto preheated substrates (e. g. FTO, Si) at $120^{\circ} \mathrm{C}$ by using an airbrush with pressure of $\sim 40 \mathrm{psi}$ [118]. The distance of nozzle and substrates around $\sim 10 \mathrm{~cm}$, and spray time will affect to the thickness of film.

Meanwhile, graphene thin film can be fabricated as CE by using dip coating method. The substrate was dipped into solution and withdrawn at a constant speed. Alcohols were usually used as solvents due to have low surface tension and relatively fast evaporation. The balance of thickness depended on the density, viscosity and the surface tension of the fluid. The dip coating method was potentially used due to low cost and less equipment required. Besides of spray and dip coating method, sputtering method was also used to fabricate graphene thin film as CE. Plasma was generated between substrate and target of the material that was used to deposit thin film. In this method, substrate was placed as the anode and target as the cathode that was emitted atoms to the surface substrate under vacuum condition [119].

\subsection{Polymer materials}

Conducting polymers were spectacular materials as CE in DSSCs application. Conducting polymer was used to replace Pt [100]. The conducting polymer like PEDOT was preferred as CE due to have electrochemical activity, transparency and high stability [120]. PEDOT as $\mathrm{CE}$ has power conversion efficiency of $\sim 4.99 \%$ by polymerization method that has high electrical conductivity to improve performance in DSSCs application [120].

\section{Operational Principle of Dye Sensitized Solar Cells}

Photovoltaic devices have two important steps to convert sunlight into electrical energy: (1) radiation absorption with electron excitation, (2) charge carrier's separation. The dye molecules under exposure of sunlight became photo-excitation and injection electrons into the conduction band of the semiconducting metal oxide. The configuration of dye will be regenerated by electron donation from the electrolyte. Electrolyte regenerates the dye by recombination of photo-excitation electrons that flow into the photoanode. Then, the electrolyte was regenerated at the $\mathrm{CE}$ when the circuit was completed by an external load.

\section{CONCLUSIONS}

The power conversion efficiency has important role in DSSCs application. The present review was given explanation about the good materials that can be used as photoanode and CE in DSSCs. The good properties of photoanode materials supposedly have a high surface area for sufficient dye adsorption, highly porous for effective mass transport by diffusion, high electron mobility for efficient electron transport and to be transparent to visible light for minimizing the loss of incident photon. $\mathrm{The}^{\mathrm{TiO}_{2}}$ was used as photoanode materials due 
to has the highest power conversion efficiency than the other semiconductor materials. However, the $\mathrm{TiO}_{2}$ has low electron mobility. Besides of $\mathrm{TiO}_{2}$, the $\mathrm{ZnO}$ was also used as photoanode due to have a higher electron mobility than $\mathrm{TiO}_{2}$. However, $\mathrm{ZnO}$ has a low power conversion efficiency in DSSCs application.

The $\mathrm{ZnO}$ and $\mathrm{TiO}_{2}$ have the similar band gap ( $>3 \mathrm{eV}$ ). Hence, bilayer $\mathrm{Zn}$ on $\mathrm{TiO}_{2}$ layer was used as photoanode in DSSCs application. The $\mathrm{Zn}$ on $\mathrm{TiO}_{2}$ layer was used to change the existing crystalline phases as well as degree of crystallinity, morphology, distribution and particle size. Meanwhile, $\mathrm{Zn}$ can enhance the photo-catalytic activity of $\mathrm{TiO}_{2}$. The synthesis of $\mathrm{Zn}$-doped $\mathrm{TiO}_{2}$ used hydrothermal method. The $\mathrm{Zn}$-doped $\mathrm{TiO}_{2}$ has the lower density that good for efficient electron in DSSCs performance. The $\mathrm{Zn}$ on $\mathrm{TiO}_{2}$ layer can improve the power conversion efficiency. This bilayer has a power conversion efficiency of $\sim 8 \%$ which the higher than mono-layer of $\mathrm{TiO}_{2}$. Bilayer structures consisted of an over and under layer that were used by light scattering for boosting the optical absorption of photoanode. Consequently, the more light absorbed and electron-hole pair injections were occurred.

Meanwhile, an excellent photoanode material supposedly has a low sheet resistance, low cost, good chemical stability, high electrical conductivity to charge transport, high reflecting properties, good electro-catalytic activity to reduce the redox couple and excellent stability. The metal Pt was popular catalyst as CE materials due to high electro-catalytic activity to the reduction of redox couples in liquid electrolytes, highly transparent and high power conversion efficiency. However, Pt was highly cost, diminishing supply and corrosion in liquid electrolyte. Consequently, other materials such as carbon, CNTs, graphene and conducting polymers have been also used as CE materials. Carbonaceous were used to replace $\mathrm{Pt}$ as CE in DSSCS due to inexpensive and readily available.

Meanwhile, graphene has been extensively explored to replace noble metal such as $\mathrm{Pt}$ as $\mathrm{CE}$ due to low cost, simple preparation, good electro-catalytic activity, high transparency, high electrical conductivity, high thermal stability, environmental friendliness, chemical and mechanical robustness and high surface area. Graphene has been intensively used as CE that has yielded high-performance of DSSCs. Graphene as CE has power conversion efficiency of $\sim 5.09 \%$ and same goes with Pt, while used as CE has efficiency of $\sim 5.09 \%$ in DSSCs application. Therefore, graphene well-known has a high power conversion efficiency and $\mathrm{Pt}$ as well. Then, the GO can be synthesized by using electrochemical exfoliation method. Afterward, the hydrazine hydrate was used as reducing agent to produce $\mathrm{rGO}$ from GO by reduction process. The reduction process was used to reduce the oxygen content in GO solution. The rGO showed the better electro-catalytic activity than the original GO.

\section{REFERENCES}

1 Dresselhaus, M.S., Thomas, I. L. 2001. Alternative energy technologies. Nature, Vol. 414, Page 332-337.

2 Sugathan, V., John, E., Sudhakar, K. 2015. Recent improvements in dye sensitized solar cells : A review. Renew. Sustain. Energy Rev, Vol. 52, Page 54-64.

3 Chapin, D. M., Fuller, C. S., Pearson, G. L. 1954. A New silicon pn junction photocell for converting solar radiation into electrical power. J. Apll. Phys, Vol. 676, Page 22-24.

4 O’Regan, B., Gratzel, M. 1991. A low-cost, high-efficiency solar cell based on dyesensitized colloidal titanium dioxide films. Nature, Vol. 353, No. 6346, Page 737-740.

5 Marwoto, P., Fatiatun, Sulhadi., Sugianto., Aryanto, D. 2016. Effects of argon pressure on the properties of $\mathrm{ZnO}$ : Ga thin films deposited by $\mathrm{DC}$ magnetron sputtering. AIP 
Conf. Proc, Vol. 1719, No. 30016.

6 Birel, O., Nadeem, S., Duman, H. 2017. Porphyrin-Based dye-sensitized solar cells ( DSSCs ): a Review. J Fluoresc, Vol. 27, Page 1075-1085.

7 Suriani, A. B., Fatiatun, Mohmed, A., Muqoyyanah., Hashim, N., Rosmi, M.S., Mamat, M.H., Malek, M.F., Salifairus, M.J., Khalil, H.P.S.A. 2018. Reduced graphene oxide/platinum hybrid counter electrode assisted by custom-made triple-tail surfactant and zinc oxide/titanium dioxide bilayer nanocomposite photoanode for enhancement of DSSCs photovoltaic performance. Opt-Int. J. Light Electron Opt, Vol. 161, Page 7083.

8 Ameer, A.A., Suriani, A.B., Jabur, A.R., Hashim, N., Fatiatun., Zaid, K. 2019. The fabrication of zinc oxide nanorods and nanowires by sol gel immersion methods. IOP Conf. Series: J. Phys, Vol. 1170.

9 Sulhadi, Fatiatun, Marwoto, P., Sugianto, Wibowo, E. 2015. Deposition temperature variations on the structure, optical and electrical properties of zinc oxide thin films doped gallium (ZnO:Ga). J. Pendidik. Fis. Indonesia, Vol. 11, No. 1.

10 Grätzel, M. 2003. Dye-sensitized solar cells. J. Photochem. Photobiol. C Photochem. Rev, Vol. 4, No. 2, Page 145-153.

11 Andualem, A., Demiss, S. Review on dye-sensitized solar cells ( DSSCs ). 2018. $J$. Heterocyclis, Vol. 1, No. 1, Page. 29-34.

12 Gong, J., Sumathy, K., Qiao, Q., Zhou, Z. 2017. Review on dye sensitized solar cells (DSSCs): advanced technique and research trends. Renew. Sustain. Energy Rev., Vol. 68, Page. 234-246.

13 Fatiatun., Suriani, A.B., Mohamed, A., Hashim, N., Mamat, M.H., Malek, M.F. 2017. The structural properties of $\mathrm{ZnO} / \mathrm{TiO}_{2}$ bilayer thin film as photoanode. Sainmatika, Vol. 14, No. 1.

14 Sengupta, D., Das, P., Mondal, B., Mukherjee, K. 2016. Effects of doping, morphology and film-thickness of photo-anode materials for dye sensitized solar cell application - A review. Renew. Sustain. Energy Rev, Vol. 60, Page 356-376.

15 Suriani. A. B., Fatiatun., Mohamed, A., Muqoyyanah., Hashim, N., Mamat, M.H., Ahmad, M.K., Marwoto, P. 2019. Improved DSSC photovoltaic performance using reduced graphene oxide - carbon nanotube/platinum assisted with customised triple tail surfactant as counter electrode and zinc oxide nanowire/titanium dioxide nanoparticle bilayer nanocomposite as photoanode. Graphene Technol, Vol. 4, Page 1731.

16 Rani, M., Tripathi, S.K. 2015. A comparative study of nanostructured $\mathrm{TiO}_{2}$, $\mathrm{ZnO}$ and bilayer $\mathrm{TiO}_{2} / \mathrm{ZnO}$ dye-sensitized solar cells. J. Electron. Mater, Vol. 44, No, 4, Page 1151-1159.

17 Ye, M., Wen, X., Wang, M., Locozzia, J., Zhang, N., Lin, C., Lin, Z. 2015. Recent advances in dye-sensitized solar cells: From photoanodes, sensitizers and electrolytes to counter electrodes. Mater. Today, Vol. 18, No. 3, Page 155-162.

18 Lee, D., Lee, H., Ahn, Y., Lee, Y. 2015. High-performance flexible transparent conductive film based on graphene/AgNW/graphene sandwich structure. Carbon, Vol. 81, Page 439-446.

19 Aouaj, M. A., Diaz, R., Belayachi, F. Rueda, Abd-lefdil, M. 2009. Comparative study of ITO and FTO thin films grown by spray pyrolysis. Mat. Res. Bull, Vol. 44, Page $1458-1461$.

20 Genesio, G., Meyer, D. 2018. Recent status on MOF Thin films on transparent conductive oxides recent status on MOF thin films on transparent conductive oxides 
substrates ( ITO or FTO ). New. J. Chem, No. 4.

21 Suhaimi, S., Shahimin, M. M., Alahmed, Z. 2015. Materials for enhanced dye-sensitized solar cell performance : electrochemical application. Int. J. Electrochem. Sci, Vol. 10, Page 2859-2871.

22 Vittal, R., Ho, K. 2016. Zinc oxide based dye-sensitized solar cells : A review," Renew. Sustain. Energy Rev., Vp. 70, Page. 920-935.

23 Arunachalam, A., Dhanapandian, S., Manoharan, C., Sridhar, R. 2015. Spectrochimica acta part A : molecular and biomolecular spectroscopy characterization of sprayed $\mathrm{TiO}_{2}$ on ITO substrates for solar cell applications. Spectrochim. Acta Part A Mol. Biomol. Spectrosc, Vol. 149, Page 904-912.

24 Zhang, Z., Gao, C., Wu, Z., Han, W. 2015. Toward efficient photoelectrochemical water-splitting by using screw-like $\mathrm{SnO}_{2}$ nanostructures as photoanode after being decorated with CdS quantum dots. Nano Energy, Vol. 19, Page 318-327.

25 Enyan, G. L. Y. 2015. Tailored $\mathrm{SrTiO}_{3} / \mathrm{TiO}_{2}$ heterostructures for dye-sensitized solar cells with enhanced photoelectric conversion performance. J. Mater. Chem. A.

26 Siwatch, S., Singh, V., Kumar, A., Kumar, S., Chauhan, N., Kumari, M. 2019. Optik Effect of novel $\mathrm{ZnO} / \mathrm{Zn}_{2} \mathrm{SnO}_{4}$ photoanode on the performance of dye sensitized solar cell. Opt -Int. J. Light Electron Opt., Vol 194, Page 163117

27 Beedri, N.. I., Baviskar, P. K. 2018. Bilayered $\mathrm{ZnO} / \mathrm{Nb}_{2} \mathrm{O}_{5}$ photoanode for dye sensitized solar cell. Inter. J. Modern. Phys. B, Vol. 32, Page 1-5.

28 Hoffmann, M. R.., Martin, S. T., Choi, W., Bahnemannt, D. W. 1995 Environmental applications of semiconductor photocatalysis. Chem. Rev, Vol. 95, Page 69-96.

29 Chai, S., Lau, T., Dayou, J., Sipaut, C. S., Mansa, R. F. 2014. Development in photoanode materials for high efficiency dye sensitized solar cells. Inter. J. Renew. En. Research, Vol. 4, No. 3.

30 Ma, J., Ren, W., Zhao, J., Yang, H. 2016. Growth of $\mathrm{TiO}_{2}$ nanoflowers photoanode for dye-sensitized solar cells. J. Alloys Compd., Vol. 692, Page 1004-1009.

31 Kang, S.H., kang, M.S., Kim, H.S., Kim, J.Y., chung, Y.Y., Smyrl, W., Sung, Y.E. 2008. Columnar rutile $\mathrm{TiO}_{2}$ based dye-sensitized solar cells by radio-frequency magnetron sputtering. J. Pow. Sourc, Vol. 184, Page 331-335.

32 Narayan, M. R. 2012. Review: Dye sensitized solar cells based on natural photosensitizers. Renew. Sustain. Energy Rev, Vol. 16, No. 1, Page 208-215.

33 Park, N., Van De Lagemaat, J., Frank, A. J. 2000. Comparison of dye-sensitized rutileand anatase-based $\mathrm{TiO}_{2}$ solar cells. J. Phys. Chem B, Vol. 104, Page 8989-8994.

34 Yang, Y., Zhao, J., Cui, C., Zhang, Y., Hu, H., Xu, L., Pan, J., Li, C., tang, W. 2016. Hydrothermal growth of $\mathrm{ZnO}$ nanowires scaffolds within mesoporous $\mathrm{TiO}_{2}$ photoanodes for dye-sensitized solar cells with enhanced efficiency. Electrochim. Acta, Vol. 196, page 348-356.

35 Li, F., Wang, G., Jiao, Y., Li, J., Xie, S. 2014. Efficiency enhancement of ZnO-based dye-sensitized solar cell by hollow $\mathrm{TiO}_{2}$ nanofibers. J. Alloys Compd., Vol. 611, Page $19-23$.

36 Li, Y., Guo, W., Wang, L., Su, Q., Jin, S., Qin, L., Gao, W., Liu, G., Hu, Z. 2015. Enhancing photoelectrical performance of dye-sensitized solar cell by doping $\mathrm{SrTiO}_{3}: \mathrm{Sm}^{3+} @ \mathrm{SiO} 2$ core-shell nanoparticles in the photoanode. Electrochim. Acta, Vol. 173, Page 656-664.

37 Li,W., Jin, G., Hu, H., Li, J., Yang, Y., Chen, Q. 2015. Phosphotungstic acid and WO 3 incorporated $\mathrm{TiO}_{2}$ thin films as novel photoanodes in dye-sensitized solar cells. Electrochim. Acta, Vol. 153, Page 499-507. 
38 Mohamed, I. M. A., Dao, V., Yasin, A. S., Choi, H., Barakat, I. M. A. 2016. Synthesis of novel $\mathrm{SnO}_{2} @ \mathrm{TiO}_{2}$ nanofibers as an efficient photoanode of dye-sensitized solar cells. Inter. J. Hydrog. Energy, Vol. 41, No. 25, Page 10578-10589.

39 Suriani, A. B., Muqoyyanah., Mohamed, A., Mamat, M. H., Hashim, N. 2018. Improving the photovoltaic performance of DSSCs using a combination of mixed-phase $\mathrm{TiO}_{2}$ nanostructure photoanode and agglomerated free reduced graphene oxide counter electrode assisted with hyperbranched surfactant. Opt.-Int. J. Light Electron Opt., Vol 158, Page 522-534.

40 Ahmadi, S., Asim, N., Alghoul, M.A., Hammadi, F.Y. 2014. The Role of physical techniques on the preparation of photoanodes for dye sensitized solar cells. Inter. J. Photoen, Vol. 2014

41 Zhang, B., Zhang, H., Wang, Z., Zhang, X., Qin, X., Dai, Y. 2017. Doping strategy to promote the charge separation in $\mathrm{BiVO}_{4}$ photoanodes. Applied Catal. B, Environ, Vol. 211, Page 258-265.

42 Liu, J., Poh, C. K., Zhan, D., Lai, L. 2013. Improved synthesis of graphene flakes from the multiple electrochemical exfoliation of graphite rod. Nano Energy, Vol. 2, No. 3, Page 377-386.

43 Kakiage, K., Tokutome, T., Iwamoto, S., Hanaya, M. 2013. Fabrication of a dyesensitized solar cell containing a $\mathrm{Mg}$-doped $\mathrm{TiO}_{2}$ electrode and ${\mathrm{a} \mathrm{Br}_{3} \_}_{-} \mathrm{Br}_{-}$redox mediator with a high open-circuit photovoltage of 1.21 V. Chem. Commun, Vol. 49, No. 179.

44 Tanyi, A. R., Rafieh, A. I., Ekaneyaka, P., Tan, A. L. 2015. Corrigendum to 'Enhanced efficiency of dye-sensitized solar cells based on $\mathrm{Mg}$ and $\mathrm{La}$ co-doped $\mathrm{TiO}_{2}$ photoanodes. Electrochim. Acta, Vol. 180, Page 1094.

45 Su, H., Huang, T-T., Chang, Y-H., Zhai, P., Hau, N. Y. 2015. The synthesis of Nbdoped $\mathrm{TiO}_{2}$ nanoparticles for improved-performance dye sensitized solar cells. Electrochim. Acta, Vol 182, Page 230-237.

46 Momeni, M. M. 2016. Dye-sensitized solar cells based on $\mathrm{Cr}$-doped $\mathrm{TiO}_{2}$ nanotube photoanodes. Rare Met., Vol. 36, Page 865-871.

47 Motlak, M., Akhtar, M. S., Barakat, N. A. M., Hamza, A. M., Yang, O. B., Yong,H. 2014. High-efficiency electrode based on nitrogen-doped $\mathrm{TiO}_{2}$ nanofibers for dyesensitized solar cells. Electrochim. Acta, Vol 115, Page 493-498.

48 Sun, Q., Zhang, J., Wang, P., Zheng, J., Zhang, X. 2013. Sulfur-doped $\mathrm{TiO}_{2}$ nanocrystalline photoanodes for dye-sensitized solar cells. J. Renew. Sustain. Ener, Vol. 4.

49 Ho, C-Y., Lin, J. K., Wang, H. 2015. Characteristics of boron decorated $\mathrm{TiO}_{2}$ nanoparticles for dye-sensitized solar cell photoanode. Inter. J. Photoenergy, Vol. 2015, Page 1-9.

50 Trung, N., Jae, S., Hee, O., Seo, J. 2014. Fabrication and characterization of electrospun carbon nanotubes/titanium dioxide nanofibers used in anodes of dye-sensitized solar cells. Synth. Met, Vol. 193, Page 125-131.

51 Hou, S., Li, C. 2016. Fabricated ZnO Nanorods on transparent conductive Ga-doped $\mathrm{ZnO}$ film as fabricated zno nanorods on transparent conductive Ga-doped $\mathrm{ZnO}$ film as photoanodes applying for dye-sensitized solar cell. Nanosci. Nanotechnol. Lett, Vol. 8, No. 7, Page 561-566.

52 Guo, X., Dong, H., Niu, G., Qiu, Y., Wang, L 2014. Mg doping in nanosheet-based spherical structured $\mathrm{ZnO}$ photoanode for quasi-solid dye-sensitized solar cells. RSC $A d v$, Vol. 4, Page 21294-21300. 
53 Dhamodharan, P., Manoharan, C., Bououdina, M., Venkadachalapathy, R., Ramalingam, S. 2017. Al-doped $\mathrm{ZnO}$ thin films grown onto ITO substrates as photoanode in dye sensitized solar cell. Sol. Energy, Vol. 141, Page 127-144.

54 Bai, J., Xu, X., Xu, L., Cui, J., Huang, D., Chen, W., Cheng, Y., Shen, Y., Wang, M. 2013. Potassium-doped zinc oxide as photocathode material in dye-sensitized solar cells. Chem. Sus. Chem, Vol. 6, Page 622-629.

55 Kamegawa, T., Matsuura, S., Seto, H., Yamashita, H. 2013. A visible-light-harvesting assembly with a sulfocalixarene linker between dyes and a $\mathrm{Pt}_{-} \mathrm{TiO}_{2}$ Photocatalyst. Angewandte. Comm, Page 916-919.

56 Kislyuk, V. V., Dimitriev, O. P. 2008. Nanorods and nanotubes for solar cells. $J$. Nanosci. Nanotechnol, Vol. 8, No. 1, No. 131-148.

57 Kathirvel, S., Su, C., Shiao, Y., Lin, Y., Chen, B., Li,W. 2016. Solvothermal synthesis of $\mathrm{TiO}_{2}$ nanorods to enhance photovoltaic performance of dye-sensitized solar cells. Sol. Energy, Vol. 132, Page 310-320.

58 Ye, M., Zheng, D., Lv, M., Chen, C., Lin, C., Lin, Z. 2013. Hierarchically structured nanotubes for highly efficient dye-sensitized solar cells. Adv. Mater, Vol. 25, Page 3039-3044.

59 Mali, S. S., Betty, C. A., Bhosale, P., Patil, P. S. 2014. From nanocorals to nanorods to nanoflowers nanoarchitecture for efficient dye-sensitized solar cells at relatively low film thickness: All Hydrothermal Process. Scientific. Report., Vol 4, Page 5451-5458.

60 Iraj, M., Nayeri, F. D., Asl-soleimani, E., Narimani, K. 2015. Controlled growth of vertically aligned $\mathrm{TiO}_{2}$ nanorod arrays using the improved hydrothermal method and their application to dye-sensitized solar cells. J. Alloys Compd., Vol. 659, Page 44-50.

61 Liao, J-Y., Lei, B-X., Chen, H-Y., Kuang, D-B. Su, C-Y. 2012. Oriented hierarchical single crystalline anatase $\mathrm{TiO}_{2}$ nanowire arrays on Ti-foil substrate for efficient flexible dye-sensitized solar cells. Energy \& Environ. Sci. Vol. 5.

62 Zhang, Y., Cai, J., Ma, Y., Qi, L. 2017. Mesocrystalline $\mathrm{TiO}_{2}$ nanosheet arrays with exposed $\{001\}$ facets : Synthesis via topotactic transformation and applications in dyesensitized solar cells. Nano. Research., Vol. 10, Page2610-2625.

63 Zhao, C., Zhang, J., Hu, Y., Robertson, N., Hu, P. A., Child, D., Gibson, D., Fu, Y. Q. 2015. In-situ microfluidic controlled, low temperature hydrothermal growth of nanoflakes for dye-sensitized solar cells. Nat. Publ. Gr., Vol. 5, No. 17750.

64 Omar, A., Abdullah, H., Yarmo, M. A., Shaari, S., Taha, M. R. 2013. Morphological and electron transport studies in $\mathrm{ZnO}$ dye-sensitized solar cells incorporating multi- and single-walled carbon nanotubes. J. Phys. D: Appl, Vol. 46.

65 Kumar, V., Singh, N., Kumar, V., Purohit, L. P., Kapoor, A., Ntwaeaborwa, O. M., Swart, H. C. 2013. Doped zinc oxide window layers for dye sensitized solar cells Doped zinc oxide window layers for dye sensitized solar cells. J. Appl. Phys, Vol. 114.

66 Zhou, Y., Zhou, W., Du, Y., Li, M., Wu, S. 2011. Sphere-like kesterite $\mathrm{Cu}_{2} \mathrm{ZnSnS}_{4}$ nanoparticles synthesized by a facile solvothermal method. Mater. Lett, Vol. 65, No. 11, Page 1535-1537.

67 Ameer, A. A., Suriani, A. B., Jabur, A. R., Hashim, N., Fatiatun., Zaid, K. 2019. The fabrication of zinc oxide nanorods and nanowires by sol-gel immersion methods. $J$. Phys. Conf. Ser, Vol. 1170.

68 Fan, J., Hao, Y., Munuera, C., Hernandez, M. H., Guell, F., Johansson, E. M. J., Boschloo, G., Hagfeldt, A., Cabot, A. 2013. Influence of the annealing atmosphere on the performance of $\mathrm{ZnO}$ nanowire dye-sensitized solar cells influence of the annealing atmosphere on the performance of zno nanowire dye-sensitized solar cells. J. Phys. 
Chem C, Vol. 117, No. 32, Page 16349-16356.

69 Wu, A. D., Gao, Z., Xu, F., Chang, J., Tao, W., He, J., Jiang, K. 2013. Hierarchical ZnO aggregates assembled by orderly aligned nanorods for dye-sensitized solar cells. Cryst Eng Comm, Vol. 15.

70 Saurdi, I., Mamat, M. H., Malek, M. F., Rusop, M. 2014. Preparation of aligned zno nanorod arrays on Sn-doped $\mathrm{ZnO}$ thin films by sonicated sol-gel immersion fabricated for dye-sensitized solar cell. Adv. Mater. Sci. Eng.

71 Tan, W. K., Lockman, Z., Razak, K. A., Kawamura, G., Muto, H., Matsuda, A. 2013. Enhanced dye-sensitized solar cells performance of $\mathrm{ZnO}$ nanorod arrays grown by lowtemperature hydrothermal reaction. Inter. J. Energy. Res.

72 Li, Z. Z. Z., Zhou, Y., Xue, G., Yu, T. 2012. Fabrication of hierarchically assembled microspheres consisting of nanoporous $\mathrm{ZnO}$ nanosheets for high-efficiency dyesensitized solar cells. J. Mater. Chem, Vol. 29.

73 Mou, J., Zhang, W., Fan, J., Deng, H., Chen, W. 2011. Facile synthesis of ZnO nanobullets/nanoflakes and their applications to dye-sensitized solar cells. J. Alloys Compd, Vol. 509, No. 3, Page 961-965.

74 Dhas, V.,Muduli, S., Lee, W., Han, S. H., Ogale, S. 2008. Enhanced conversion efficiency in dye-sensitized solar cells based on $\mathrm{ZnO}$ bifunctional nanoflowers loaded with gold nanoparticles. Appl. Phys. Lett, Vol. 93, Page 1-4.

75 Amin, G., Asif, M. H., Zainelabdin, A., Zaman, S., Nur, O., Willander, M. 2011. Influence of $\mathrm{pH}$, precursor concentration, growth time, and temperature on the morphology of $\mathrm{ZnO}$ nanostructures grown by the hydrothermal method. J. Nanomat, Vol. 2011.

76 Malek, M. F., Mamat, M. H., Soga, T., Rahman, S. A., Suriani, A. B., Ismail, A. S., Rusop. M. 2016. Thickness-controlled synthesis of vertically aligned c -axis oriented $\mathrm{ZnO}$ nanorod arrays: Effect of growth time via novel dual sonication sol-gel process. Jpn. J. Appl. Phys, Vol. 55, Page 01 AE15.

77 Kwak, C., Woo, H., Abdel-hady, F., Wazzan, A. A., Lee, J. 2015. Vapour-phase growth of urchin-like $\mathrm{Mg}$-doped $\mathrm{ZnO}$ nanowire networks and their application to highly sensitive and selective detection of ethanol. Sensors Actuators B. Chem., Vol. 223, Page 527-534.

78 Xu, C. H., You, Y. F., Wang, J. Z., Ge, S. F., Fong, W. K. Leung, K., Surya, C. 2013. Growth behavior of $\mathrm{ZnO}$ nanowires on $\mathrm{Au}$-seeded $\mathrm{SiO}_{2}-\mathrm{GaN}$ co-substrate by vapor transport and deposition. Superlattices and Microstructures, Vol. 61, Page 97-105.

79 Kim, K. H., Utashiro, K., Abe, Y., Kawamura, M. 2014. Growth of zinc oxide nanorods using various seed layer annealing temperatures and substrate materials. Materials, Vol. 9, Page 2080-2089.

80 Lien, S. T., Chen, J. Z., Yang, Y. J., Hsu, C. C., Cheng, I. C. 2014. Sol-gel derived amorphous/nanocrystalline $\mathrm{MgZnO}$ thin films annealed by atmospheric pressure plasma jets. Ceram. Int, Vol. 40, No. 2, Page 2707-2715.

81 Zhang, D. 2012. Enhancement of the photocatalytic activity of modified $\mathrm{TiO}_{2}$ nanoparticles with $\mathrm{Zn}_{2}{ }^{+}$. Correlation between Structure and Properties 1. Russian J Phys Chem A, Vol. 86, No. 3, Page 489-494.

82 Wang, Y. 2009. Research progress on a novel conductive polymer-poly(3,4ethylenedioxythiophene) (PEDOT). J. Phys. Conf. Ser, Vol. 152.

83 Zhu, F., Zhang, P., Wu, X., Fu, L., Zhang, J., Xu, D. 2012. The origin of higher opencircuit voltage in zn-doped $\mathrm{TiO}_{2}$ nanoparticle-based dye-sensitized solar cells. Chem Phys Chem. 
84 Jena, A. V. G., Mohanty, S. P., Kumar, P., Naduvath, J., Lekha, P. B. P., Das, J., Narula, H. K. 2012. Dye sensitized solar cells: A review. Top. Rev, Vol. 71, No. 1.

85 Chandra, N., Nath, D., Kim, C., Kim, P., Lee, J. 2013. Deprotonation of N3 Adsorbed on $\mathrm{TiO}_{2}$ for high-performance dye-sensitized solar cells (DSSCs). J. Mat. Chem. A, Vol. 1, Page 13439-13442.

86 Campbell, W. M., Jolley, K. W., Wagner, P., Wagner, K., Walsh, K. W. 2007. Highly efficient porphyrin sensitizers for dye-sensitized solar cells. J. Phys. Chem. C, Vol. 36, No. 3, Page 11760-11762.

87 Yao, Z., Zhng, M., Wu, H. W., Li, R., Wang, P. 2015. A donor-acceptor indenoperylene dye for highly efficient organic dye-sensitized solar cells. J. Am. Chem. Soc., Vol. 137, No. 11, Page 3799-3802.

88 Sengupta, D., Mondal, B., Mukherjee, K. 2015. Visible light absorption and photosensitizing properties of spinach leaves. Spectrochim. Acta Part A Mol. Biomol. Spectrosc, Vol. 148, Page 85-92.

89 Senthil, R. A., Theerthagiri, J., Madhavan, J., Arof, A. K. 2016. Performance characteristics of guanine incorporated PVDF-HFP/PEO polymer blend electrolytes with binary iodide salts for dye-sensitized solar cells. Opt. Mater. (Amst)., Vol. 58, Page 357-364.

90 Yen, Y.-S., Chou, H.-H., Chen, Y.-C., Hsu, C.-Y., Lin, J. T. Recent developments in molecule-based organic materials for dye-sensitized solar cells. J. Mater. Chem. Vol. 22, Page 8734-8747.

91 Nagarajan, B., Kushwara, S., Elumalai, R., Mandal, S. Ramanujam, K., Raghavachari, D. 2017. Novel ethynyl-pyrene substituted phenothiazine based metal free organic dyes in DSSC with $12 \%$ conversion efficiency. Materials Chemistry A, Vol. 21.

92 Zanni, M. T., Greenblatt, B. J., Davis, A. V. 1999. Photodissociation of gas phase I3 2 using femtosecond photoelectron spectroscopy. J. Chem. Phys, Vol. 111, No. 7.

93 Kebede, Z., Lindquist, S. 1999. Donor- acceptor interaction between non-aqueous solvents and I to generate I, and its implication in dye sensitized solar cells. Sol. Ener. Mat \& Sol Cells, Vol. 57, Page 259-275.

94 Bella, F., Pugliese, D., Zolin, L., Gerbaldi, C. 2014. Paper-based quasi-solid dyesensitized solar cells. J. Power Sources, Vol. 237, Page 87-93.

95 Achari, M. B., Elumalai, V., Safdari, K. M., Gao, J. 2013. Quasi-liquid polymer-based cobalt redox mediator electrolyte for dyesensitized solar cells. Phys. Chem. Chem. Phys, Vol. 40.

96 Chen, H-Y., Lin, L., Yu, X-Y., Qiu, K-Q., Lu, X-Y., Kuang, D-B., Su, C-Y. 2013. Dextran based highly conductive hydrogel polysulfide electrolyte for effiicient quasisolid-state quantum dot-sensitized solar cells. Electrochim. Acta, Vol. 92, Page 117123.

97 Thomas, S. V. N. S., Deepak, T. G., Anjusree, G. S., Arun, T. A., Nair, A. S. 2014. A review on counter electrode materials in dye-sensitized solar cells. J. Mater. Chem. A, Vol. 2.

98 Jumini, S., Fatiatun., Suriani, A. B., Marwoto, P. 2019. The structural , optical and electrical properties of graphene oxide-based counter electrode. Inter. J. Adv. Mutidis. Sci. Res, Vol. 2, No. 3, Page 1-8.

99 Wang, H., Sun, K., Tao, F., Stacchiola, D. J., Hu, Y. H. 2013. 3D honeycomb-like structured graphene and its high efficiency as a counter-electrode catalyst for dyesensitized solar cells. Angew. Chemie - Int. Ed, Vol. 52, No. 35, Page 9210-9214.

100 Chang, L. H., Hieh, C. K., Hsiao, M. C., Chiang, J. C., Liu, P. I., Ho, K K., Ma, C. C. 
M., Yen, M. Y., Tsai, M. C., Tsai, C. H. 2013. A graphene-multi-walled carbon nanotube hybrid supported on fluorinated tin oxide as a counter electrode of dyesensitized solar cells. J. Power Sources, Vol. 222, Page 518-525.

101 Chang, Q., Ma, Z., Wang, J., Yan, Y., Shi, W., Chen, Q., Huang, Y., Yu, Q., Huang, L. 2014. Graphene nanosheets inserted by silver nanoparticles as zero-dimensional nanospacers for dye sensitized solar cells. Nanoscale, Vol. 10, Page 5410-5415).

102 Kamau, G. N. 1988. Surface preparation od glasy carbon electrodes. Analytica Chimica Acta, Vol. 207, Page 1-16.

103 Yang, W., Ma, X., Xu, X., Li, Y., Raj, S. I., Ning, G., Wang, A., Chen, S. 2015. Sulfurdoped porous carbon as metal-free counter electrode for high- efficiency dye-sensitized solar cells. J. Power Sources, Vol. 282, Page 228-234.

104 Ma, J., Li, C., Yu, F., Chen, J. 2015. Brick-like' N-doped graphene/carbon nanotube structure forming three-dimensional films as high performance metal-free counter electrodes in dye-sensitized solar cells. J. Power Sources, Vol. 273, Page 1048-1055.

105 Kole, M., Dey, T. K. 2013. Investigation of thermal conductivity, viscosity, and electrical conductivity of graphene based nanofluids. J. Appl. Phys, Vol. 113, No. 8.

106 Parvez, K., Wu, Z., Li, R., Liu, X., Graf, R. 2014. Exfoliation of graphite into graphene in aqueous solutions. J. Am. Chem. Soc, Vol. 136, Page 6083-6091.

107 Li, Z., Song, B., Wu, Z., Lin, Z., Yao, Y., Moon, K. S., Wong, C. P. 2015. 3D porous graphene with ultrahigh surface area for microscale capacitive deionization. Nano Energy, Vol. 11, Page 711-718.

108 Ovid'ko, I. 2013. Mechanical properties of graphene. Rev. Adv. Mater. Sci, Vol. 34, Page 1-11.

109 Yu, Y-H., Chi, W-F, Huang, W-C, Wang, W-S., Shih, C-J., Tsai, C-H. 2016. Highefficiency counter electrodes using graphene hybrid with a macrocyclic nickel complex for dye sensitized solar cells. Organic. Electronics, Vol. 31, Page 207-216.

110 Liu, H., Liang, S. P., Wu, T. J., Chang, H., Kao, P. K. 2014. Rapid atmospheric pressure plasma jet processed reduced graphene oxide counter electrodes for dye-sensitized solar cells. ACS Appl. Mater. Interfaces, Vol. 6, No. 17, Page 15105-15112.

111 Zaaba, N. I., Foo, K. L., Hashim, U., Tan, S. J., Liu, W. W., Voon, C-H. 2017. Synthesis of graphene oxide using modified hummers method: solvent influence, Procedia Eng., Vol. 184, Page 469-477.

112 Chen, J., Yao, B., Li, C. Shi. 2013. An improved Hummers method for eco-friendly synthesis of graphene oxide. Carbon, Vol. 4, No. 1, Page 225-229.

113 Gomaa, M., Fattah, G. A. 2016. Synthesis of graphene and graphene oxide by microwave plasma chemical vapor deposition. J. American. Sci, Vol. 12, No. 3, Page $72-80$.

$114 \mathrm{Xu}, \mathrm{CP}$. Shin, L. Cao, Gao, D. 2017. Preferential Growth of long zno nanowire array and its application in dye-sensitized solar cells. Interm J, Vol. 2010.

115 Jiao, K., Zhang, D., Chen. Y. 2014. Efficient and cost-effective grapene on silicon solar cells prepared by spray coating. RSC. Adv, Vol. 4, Page 55300-55304.

116 Panthi, D., Tsutsumi, A. 2014. A novel multistep dip-coating method for the fabrication of anode-supported microtubular solid oxide fuel cells. J. Solid. State. Electrochem., Vol. 18, Page 1899-1905.

117 Ke, C-R., Ching, C-C., Ting, J-M. 2015. Modified conducting polymer film having high catalytic activity for use as counter electrodes in rigid and flexible dye-sensitized solar cells. J. Power. Sources., Vol. 284, Page 489-496. 